\section{Ability to Overcome Border Guards' Psychological Barriers During the Covid-19 Pandemic}

\author{
Dmytro OLESHKO'1, \\ Maksym FILIPPOV', \\ Yurii BETS3, \\ Iryna BASARABA, \\ Iryna BETS5, \\ Artem BRATKO 6
}

${ }^{1} \mathrm{Ph} . \mathrm{D}$. in Psychology, Lecturer of the Border Guard Service Department, BohdanKhmelnytskyi National Academy of the State Border Guard Service of Ukraine, Khmelnytskyi, Ukraine. oleshko104@ukr.net ${ }^{2}$ Ph. D. in Psychology, Associate Professor of the General Military Disciplines

Department, BohdanKhmelnytskyi National Academy of the State Border Guard Service of Ukraine, Khmelnytskyi, Ukraine.

maxfee18895@gmail.com

${ }^{3} \mathrm{Ph}$. D. in Pedagogics, Associate Professor of the Foreign Languages Department, Bohdan Khmelnytskyi National Academy of the State Border Guard Service of Ukraine, Khmelnytskyi, Ukraine. vuzhm75@i.ua ${ }^{4}$ Lecturer of the Foreign Languages Department, Bohdan Khmelnytskyi National Academy of the State Border Guard Service of Ukraine, Khmelnytskyi, Ukraine.

\section{irynaborovyk2017@ukr.net}

${ }^{5} \mathrm{Ph}$. D. in Pedagogics, Associate Professor, Senior Lecturer of the Foreign Languages Department, Bohdan Khmelnytskyi National Academy of the State Border Guard Service of Ukraine, Khmelnytskyi, Ukraine.

irchikan79@ukr.net

${ }^{6} \mathrm{Ph}$. D. in Military Sciences, Associate Professor of the General Military Disciplines Department, BohdanKhmelnytskyi National Academy of the State Border Guard Service of Ukraine, Khmelnytskyi, Ukraine.

bratkoav84@gmail.com
Abstract: The article reveals an analysis of the ability of border guards to overcome psychological barriers during the COVID19 pandemic. In the last few months, the psychological strain in the world due to the COVID-19 pandemic has increased significantly, which has affected the ability of border guards to overcome psychological barriers. The article examines the impact of such psychological support in the form of online classes and provides recommendations for the applied use of the program to develop the ability to overcome border guards' psychological barriers, developed by the authors. The authors suggested a number of methods to test the ability in order to overcome the psychological barriers of border guards in difficult working conditions, and also tested these methods. To examine the ability of border guards to overcome psychological barriers during the COVID-19 pandemic, an online survey of respondents was conducted. The results of the survey were compared with the results in 2014. The study also included the testing of online training programs, which provided for the simulation of service situations in order to correct the errors that are most common done by officers. A constructive part of the study was the research and analysis of psychoregulation and correction of negative, uncomfortable states, emotional, affective and sensory spheres. At the final stage there was a consolidation of the positive results achieved in the process of classes, discussion by the students of the group of experience, emotions, own states.

Keywords: Border guards, overcoming psychological barriers, analysis of psychological state, a program to develop the ability to overcome psychological barriers, psychological barriers during the COVID-19 pandemic.

How to cite: Oleshko, D., Filippov, M., Bets, Y., Basaraba, I., Bets, I., \& Bratko, A. (2020). Ability to Overcome Border Guards' Psychological Barriers During the Covid-19 Pandemic. Journal of Mediation \& Social Welfare, 2(1), 44-59. https://doi.org/10.18662/jmsw/2.1/11 



\section{Introduction}

Daily professional activity of the border guard is full of tense situations, especially in the conditions of the COVID-19 pandemic, which requires sufficient reserves of self-government and self-regulation from it, which would allow him to withstand the influence of strong stimuli, to show patience, balance, collection, restraint in these situations and the ability to maintain effective work throughout the service period.

Low level of self-regulation skills in the context of the COVID-19 pandemic leads to the fact that the officer feels a state of tension, discomfort, anxiety, stress, which, in turn, reduces the efficiency of his work, increases conflict, disrupts his mental and physical health. Only an emotionally mature person is able to cope with any psychological barriers, the content of which significantly affects such qualitative and quantitative indicators of the professional activity of the border guard, as satisfaction, interest in professional activity, efficiency, degree of intensity of mental functions and processes which ensure the achievement of the goals of this activity (Zgueb, 2020).

Thus, the relevance of the study of the ability of border guards to overcome psychological barriers in a pandemic COVID-19 is conditioned by the need to increase the level of their professionalism in the field of the state border protection, which requires the ability to seek and find a way out of difficult professional situations; suggest non-standard ways to solve them, at the same time constantly to exercise self-control over the activity and behavior. Thus, the socio-psychological significance of this problem and its insufficient study in the current psychology of activity in the conditions in particular - the COVID-19 pandemic, and stipulated the choice of the research topic, the scientific task of which is the analysis of the ability of border guards to overcome psychological barriers in service activity in a pandemic COVID-19.

\section{Characteristic researching views.}

At present, there are a large number of studies devoted to the study of psychological barriers: barriers to communication, emotional and semantic barriers, barriers to perception, psychological barriers to pedagogical activity, psychological barriers in the professional selfdetermination of personality, etc. Meanwhile, until now, the problem of development of border guard's ability to overcome psychological barriers and psychological development remains virtually undeveloped in his service activity, there are no specific systematic research of features of the 
manifestation of this phenomenon in the psychology of activity in special conditions, especially in a COVID-19 pandemic.

\section{Materials and Methods}

The purpose of the article is to analyze the ability of border guards to overcome psychological barriers that arise in their professional activities in a COVID-19 pandemic.

For research the special technique of border guards' psychological barriers was developed, arising in the course of carrying out their professional activity in the conditions of the COVID-19 pandemic. Officers of units of the State Border Guard Service of Ukraine of the Western Regional Directorate became the experimental base of the research. The study was conducted through online communication with border guards through electronic means, namely: Viber, WhatsApp, ZOOM and Telegram.

\section{Results of Research}

\section{Overcoming border guards' psychological barriers. Theory.}

Issues of psychological support of professional activity in the context of psychological support of personal well-being of personnel and servicemen of law enforcement agencies in different countries of the world, including in Ukraine, is extremely relevant, especially important now is the study of the ability to overcome border guards' psychological barriers during the COVID-19 pandemic. Since the personal well-being of the staff of the State Border Guard Service of Ukraine (hereinafter - the SBGSU), which is seen, first, as a global, holistic subjective reflexive experience by border guards of the positivity and significance of their own "self-existence" as a whole and through the prism of their realization in the environment of professional activity, which represents an integrated assessment of life, positive effects on the work performed, the organizational environment and, as a consequence, life in general, and, secondly, as a subjective experienceliving of situational experience in the context of professional activity in difficult, special and extreme conditions of ensuring effective the state border protection, as a harmonious combination of efforts to implement the functions, achieved goals and benefits (rewards, recognition, prospects, etc.); it determines not only the quality of life of the border guard, but also the quality of his tasks for the state border protection and the state border security in general (WHO, 2020).

Social distancing is deliberately increasing the physical space between people to avoid spreading illness. Staying at least six feet away from 
other people lessens your chances of catching COVID-19. People who have been exposed to the new coronavirus and who are at risk for coming down with COVID-19 might practice self-quarantine. Health experts recommend that self-quarantine lasts 14 days. Two weeks provides enough time for them to know whether or not they will become ill and be contagious to other people. There are some reasons for people, border guards, in particular, to face psychological barriers to overcome. Also researches discover some stressors during quarantine. Among them are: duration of quarantine, fears of infection, frustration and boredom, inadequate supplies, inadequate information (WHO, 2020).

Lack of comprehensive psychodiagnostic methods to study the ability to overcome border guards' psychological barriers during the COVID-19 pandemic, assistance in the impact on various aspects of the personal well-being of border guards requires the development of measures for its psychological support. Several months have passed since we first heard in Ukraine about the coronavirus epidemic in the distant Chinese city of Wuhan. At that time, the events in China were perceived as something otherworldly, as a purely local event that will not affect us, the Ukrainians, in any way. But already in January of the new year 2020, media reports from the Chinese epidemiological center began to become alarming and dramatic, coronavirus crossed the borders of one country, which alone put up a courageous resistance to the disease, quickly and intelligently reorganizing the lifestyle of the world's largest population. There is a growing amount of information about the infection of this dangerous type of virus in China's neighboring Asian countries - South Korea, Japan, Vietnam, Iran, India and others. In February, the epidemic zone expands beyond Asia, with increasing outbreaks of the disease in Europe, North and South America, Australia, and Africa. Dramatic events include thousands of deaths from specific pneumonia caused by coronavirus, tens and hundreds of thousands of people affected by the new virus and millions of people living in anxiety and panic around the world. (Steenkamp et al., 2015)

On March 11, 2020, the World Health Organization (WHO) announced the onset of the COVID-19 pandemic.

According to the WHO, a pandemic is the spread of a new disease worldwide. It is characterized by a lack of collective immunity of humanity and, as a rule, effective means of testing, prevention (vaccination) and treatment of the disease (WHO, 2020).

The Director-General of the organization, Tedros Adhanom Ghebreyesus, said at a special briefing that the world has never before faced a pandemic caused by a coronavirus and which is very difficult to control. 
Countries around the world can change the course of this pandemic, prevent outbreaks of the disease, if they identify and isolate patients in time. "This is not just a health crisis, this is a crisis that will affect every sector of human life - so every sector and every person must be involved in the fight," emphasized Ghebreyesus (WHO, 2020).

The WHO Director-General called on countries to develop a strategy to prevent the spread of infection and advised to activate and expand emergency response mechanisms, explain to people the risks and ways of self-defense, find, isolate, test and provide treatment for each person infected with the coronavirus, as well as track all those with whom he came in contact. He called for the preparation of hospitals, the training of health care employees and more care for each other.

On March 17, 2020, the Verkhovna Rada of Ukraine adopted Bill № 3215 , aimed at preventing the emergence and spread of coronavirus COVID-19, and on the same day the President of Ukraine signed the law on combating coronavirus. V. Zelensky's address to the Ukrainian people announced a number of measures by the state, such as closing the border to foreigners, restricting regular flights, medical examinations to identify infected and sick, temporarily banning mass events, quarantine throughout the country. He called on Ukrainians to refrain from traveling abroad, announced the mobilization of the health care system, the purchase of necessary medical equipment and tests, equipment of 12,000 hospital beds and training of medical staff, production of 10 million masks and so on.

The President gave a number of pieces of advice to citizens on prevention and hygiene, such as food and water control, if possible to stay at home, attention to the elderly people, the transition of educational institutions to distance learning, a recommendation to managers to transfer, if possible, employees for functional responsibilities at home, etc.

A new psychological crisis intervention model by implementing a centralised psychological support system had been developed by the researches in some countries to provide psychological intervention to the general population and medical staff (Zgueb, 2020).

Particular attention was paid to the personal hygiene of everyone wearing personal protective equipment (face masks, respirators, etc.), regular hand washing, changing traditional habits, eliminating physical contact when greeting, the formation of critical thinking.

The situation in the conditions of a coronavirus pandemic is dangerous not only for physical and human health, but also for mental and psychological health. To understand the effect of COVID-19 on mental health and wellbeing, it is more important than ever that the highest 
standards of ethical research practice are maintained. Such standards include respecting confidentiality, recognising potential harms, and focusing on issues around acceptability (of potential interventions) and trustworthiness (in terms of data collection and data sharing) (Pomytkin, 2020).

Psycho-emotional destabilization of the individual in the context of the COVID-19 pandemic leads to a loss of basic sense of security (Pomytkin, 2020). This is the result of simultaneous multi-channel information exposure to highlight the speed of the virus, the consequences of infection, the number of deaths, economic losses, as well as rules of conduct, restrictions, forecasts, etc. As a result, there is mental overload, which is manifested in the background of increased anxiety with wave-like "jumps" of fear and panic, as well as - in repressed fears, subconscious attempts to control the situation more than it seems on a conscious level. Therefore, today it is extremely important emotional intelligence and a special style of human thinking, which are combined in the concept of "sanogenic thinking" suggested by psychologist Yu. Orlov (2006).

The term "sanogenic" means "health" (from the Latin "sanitas") and "origin" (from the Greek "genesis"). Sanogenic thinking can rightly be called "antiviral" or "recovering" thinking. It is aimed at counteracting and overcoming destructive emotional states and mental recovery.

The founder of the concept of sanogenic thinking Yu. Orlov came to the conclusion about the relationship of emotions and the process of human thinking: with the conscious use of certain mental schemes it is possible to regulate your emotional state, prevent negative emotions and thus affect somatic health (Orlov, 2006).

Yu. Orlov (Orlov, 2006) showed at the level of technology how to treat pathogenic emotions of anxiety, guilt, resentment, anger, aggression, etc. Sanogenic thinking in working with such emotions acquires the features of emotional intelligence. It provides:

1. Reflection or introspection of negative images or emotions, due to which they are immediately separated from the subject, and then he seems to distance himself from them, and therefore they lose or weaken their power and their negative impact on the individual.

2. Such introspection should be carried out against the background of deep inner peace, relaxation due to autogenic training, when the action of negative emotions noticeably fades, they lose the sharpness of their impact on the subject.

3. Sanogenic thinking involves the concretization of the idea of the structure of negative emotional states, so that indefinite terrible feelings become more definite, more familiar and therefore safer. 
4. Sanogenic thinking seeks the origin of vulnerable emotion, its causes, which also weakens it.

5. Sanogenic thinking requires a high level of concentration on the object of experience, because of which the subject masters it, controls it, limits it, which also leads to the extinction of the force of its negative impact. Thus, sanogenic thinking reduces the intensity of the negative effects of these destructive emotions and ensures the recovery of the individual in a pandemic COVID-19.

To examine the ability of border guards to overcome psychological barriers during the COVID-19 pandemic, an online survey of respondents was conducted. The results of the survey were compared with the results of a similar survey in 2014, conducted as part of the dissertation research of D. Oleshko (Oleshko, 2014).

Thus, our assumption was that the success of overcoming the barrier situation would depend in many respects on the positive self-esteem of the individual.

\section{Table 1. Expert assessment questionnaire Source: Authors' own conception}

\begin{tabular}{|c|}
\hline Expert assessment questionnaire \\
\hline $\begin{array}{l}\text { Dear colleague! Dear colleague! We ask you to take part in the expert } \\
\text { assessment of the psychological characteristics of the barrier-resistant } \\
\text { personality. Your task is to express your opinion about these characteristics } \\
\text { and their psychological content, if you find it necessary - supplement them, } \\
\text { and we ask you to rely not only on your knowledge in this area, but also } \\
\text { personal experience. }\end{array}$ \\
\hline $\begin{array}{l}\text { 1. Given the fact that physical conditions affect the behavior of the officer in } \\
\text { the process of professional activity, and the emotional load in his } \\
\text { professional activities are constant, will the statement that officers often } \\
\text { have psychological barriers be true? }\end{array}$ \\
\hline That's right. \\
\hline It seems so. \\
\hline Difficult to answer. \\
\hline Not true. \\
\hline $\begin{array}{l}\text { 2. Would it be true that a person with an internal locus of control is capable } \\
\text { of constructively resolving psychological barriers? }\end{array}$ \\
\hline
\end{tabular}


Ability to Overcome Border Guards' Psychological Barriers During the ... Dmytro OLESHKO, et al.

\begin{tabular}{|c|c|c|c|c|}
\hline \multicolumn{4}{|l|}{ That's right. } & \\
\hline \multicolumn{3}{|l|}{ It seems so. } & & \\
\hline \multicolumn{3}{|l|}{ Difficult to answer. } & & \\
\hline \multicolumn{3}{|c|}{ Not true. } & & \\
\hline \multicolumn{4}{|c|}{$\begin{array}{l}\text { 3. According to the type of response to a frustrating situation (according to } \\
\text { Rosentzweig), people are divided into three types: extrapunitive, } \\
\text { intropunitive and impunitive. To what type is a person with a low degree of } \\
\text { barrier-resistant behavior closer? Note. }\end{array}$} & \\
\hline \multicolumn{5}{|c|}{$\begin{array}{l}\text { 4. Do you agree that the barrier-resistance of personality is characterized by } \\
\text { such indicators? }\end{array}$} \\
\hline \multirow[b]{2}{*}{ Indicators } & \multicolumn{4}{|c|}{ Answer options } \\
\hline & $\begin{array}{c}\text { Yes, } \\
\text { I agree }\end{array}$ & $\begin{array}{c}\text { It seems } \\
\text { so }\end{array}$ & & $\begin{array}{l}\text { ifficult to } \\
\text { answer }\end{array}$ \\
\hline \multicolumn{5}{|l|}{ Low level of neuroticism } \\
\hline \multicolumn{5}{|c|}{$\begin{array}{l}\text { Ability to overcome the state of excessive } \\
\text { emotional disturbance }\end{array}$} \\
\hline \multicolumn{5}{|c|}{ High level of awareness of emotional behavior } \\
\hline \multicolumn{5}{|l|}{ Tranquility } \\
\hline \multicolumn{5}{|l|}{ Behavior flexibility } \\
\hline \multicolumn{5}{|l|}{ Emotional stability } \\
\hline \multicolumn{5}{|l|}{ High professional motivation } \\
\hline \multicolumn{5}{|l|}{ Adequacy of perception of events } \\
\hline \multicolumn{4}{|c|}{$\begin{array}{l}\text { 5. What characteristics of barrier-resistant personality and personality of } \\
\text { attitudes and behaviors, in your opinion, should be noted more? Write, } \\
\text { please. }\end{array}$} & \\
\hline
\end{tabular}

Relying on the hypothesis that dissatisfaction with their capabilities, a sense of weakness, the inability to command respect, which correspond to low indicators on the scale of "self-esteem", reinforce negative emotional states, causing frustration of the officer in difficult situations.

The next stage of the research was to test the programs online (Rybalka et al., 2020), which involved modeling service situations, which 
help to understand the mistakes that are most often encountered. The work was carried out with officers of the Western Regional Directorate of the State Border Guard Service of Ukraine during March-May 2020. The experiment involved 27 people from each of the experimental and control groups. Corrective online activities with the officers of the experimental group were carried out with a program aimed at developing the skills of physical self-control. This course was aimed at solving the following problems:

expansion of the sphere of awareness in the understanding of the owners' physical states caused by barriers in professional activity;

- harmonization of the inner world of the officer at the expense of acquisition of new knowledge and skills of physical selfregulation, adequate removal of emotional;

fulfillment; actualization and expansion of motives of professional self-

strengthening of personal and professional self-esteem of officers, awareness of their individual-psychological features and creative abilities.

Intensity of online classes - 1 time per week, duration of each class 2 hours. The program includes three main stages: the first stage preparatory, the second stage - the constructive part, the third stage - final.

The purpose of the first stage is to prepare students for the lesson, to create the appropriate settings. This stage included relaxation exercises. The constructive part was a stage of psychoregulation and correction of negative, uncomfortable states, emotional, affective-sensory sphere. The purpose of the final stage was to consolidate the positive results achieved in the process of classes, discussion by the students in groups of experience, emotions and own states. The practical implementation of the program of constructive change of the officer's behavior, the development of his barrier-resistance was carried out in the form of workshops and trainings. The work provided both different types of online trainings, psychological tests, role-plays, as well as traditional forms of work with officers - online lectures, classes, round tables.

The main purpose of the online scientific-practical seminar is to acquaint officers with simple, accessible methods of stress relief. The purpose of the training seminar is to develop the ability to manage one's psychophysical condition, to control one's behavior. The following groups of methods were used: 
- $\quad$ free drawing with a conversation about pictures: imaginary transformation of an officer into a part of a picture, composing a story on behalf of a part of a picture;

- $\quad$ relaxation games that help to relieve mental stress and help to suppress negative emotions, anger, irritation, increased anxiety and anxiety;

- $\quad$ psycho-technical exercises that help to improve professional skills, learn to quickly relieve fatigue and stress, to restore efficiency, to optimally build communication with others;

- - dramatization games, in the framework of which small performances were played out on the basis of the content of the previously performed drawing or specially suggested fairy tales-metaphors, which contained a problem close to the problem of a particular officer.

To study the ability of border officers to overcome psychological barriers during the COVID-19 pandemic, it is recommended to use such a scheme of analysis of forms and methods of organizing the barrier-resistant activity of an officer in service activity.

I. Preliminary monitoring.

- Analysis of infrastructure and internal environment in the state border protection units:

- availability of a dining room with hot food;

- $\quad$ availability of toilets with proper facilities;

- $\quad$ the presence of the officer's office and workplace;

- $\quad$ equipment of officer's service rooms;

- $\quad$ availability of office space with the necessary educational and methodical equipment;

- $\quad$ availability of a daily room;

- analysis of the organization of the professional activity of the

officer;

- $\quad$ analysis of the psychological climate in the staff;

- $\quad$ analysis of the state of medical care and the state of health of

officers:

- $\quad$ frequency of morbidity among the officers' staff;

- $\quad$ long-term illnesses among officers;

- $\quad$ the presence of healthcare center for officers;

II. Selection of factors of tension of professional activity:

External:

- $\quad$ service employment;

- $\quad$ facing with new, difficult situations;

- $\quad$ increased intellectual loads; 
- $\quad$ tense relations in the service staff;

- $\quad$ delays in the payment of pay service.

Internal:

- $\quad$ dissatisfaction with the state of one's physical health;

- dissatisfaction with the state of health of members of the family;

- $\quad$ dissatisfaction with creative self-realization at work;

- $\quad$ dissatisfaction with one's status in society;

- $\quad$ dissatisfaction with leisure activities;

- dissatisfaction with housing conditions.

III. Carrying out of complex preventive work. The proposed program is aimed at developing the barrier-resistant behavior of border guards.

This course is aimed at solving the following problems:

expansion of the sphere of the conscious in the understanding of own physical states caused by barriers in professional activity;

- harmonization of the inner world of the border guard at the expense of acquisition of new knowledge, skills of physical self-regulation, adequacy of withdrawal of the emotional tension;

fulfillment; actualization and expansion of motives of professional self-

- $\quad$ strengthening the personal and professional self-esteem of officers, their awareness of their personal abilities and creative abilities.

Topics:

1. Introduction to the concept of barrier-resistant behavior.

Psychological barriers. Solving barrier situations. Ability to overcome barriers. Differences in perception of difficulties in professional activity.

2. Emotions and feelings. Emotions and feelings of a person. What are they? A person has the right to feel what he or she wants. Awareness of one's feelings and their adequate manifestation as a necessary condition of health and success. How to manage emotions? The ability to control one's feelings as an integral part of a happy person. Hidden problems. Feelings of anxiety and worry. Our affections. Self-regulation of the emotional state.

3. Mental health. Physical health as a goal and criterion of success in professional activity. Psychological comfort as a prophylaxis of psychosomatic diseases. Barrier-resistanse: search in a difficult situation of forces in itself and as a consequence of that positive changes. 
4. "Professional crises". The importance of crises in human life. Psychological support in a crisis situation. Emotional burnout syndrome.

5. Stress. What is stress? Types of stress. Is stress good or bad? Consequences of stress. Stress situations. How to deal with stress? Stress and depression.

6. Conflicts. What is a conflict? Conflicts at work, at home, outside of service. Ways of behavior in conflict. Problems of mutual understanding between officers and their subordinates. Conflicts in the unit: how to prevent and resolve them. Expression of anger. "How to fairly divide an orange". Game tasks to raise awareness of barriers to professional communication.

7. Luck. What does it mean to be lucky? What kind of person can be lucky? Ability to overcome barriers as part of luck. Is a lucky person always happy? How to become lucky and happy.

In the fourth stage of the online interview process, during the interviews, the officers studied how to overcome psychological barriers in the control and experimental groups. With the help of content analysis, all the described methods were classified according to two criteria: constructive and non-constructive. Analysis of the interviews emphasized in the process of online interviews with the officers who overcame the psychological barriers in the control and experimental groups presented in Table 2 showed that in the experimental group $70.4 \%$ of constructive methods, in the control group - only $40.7 \%$ of constructive methods were named.

\section{Table 2. Methods of overcoming psychological barriers, in $\%$ Source: Authors' own conception}

\begin{tabular}{|l|c|c|c|c|}
\hline \multirow{2}{*}{ Groups } & \multicolumn{4}{|c|}{ Ways to overcome barriers } \\
\cline { 2 - 5 } & \multicolumn{2}{|c|}{ Constructive } & \multicolumn{2}{c|}{ Non-constructive } \\
\cline { 2 - 5 } & $\begin{array}{c}\text { Before } \\
\text { experiment }\end{array}$ & $\begin{array}{c}\text { After } \\
\text { experiment }\end{array}$ & $\begin{array}{c}\text { Before } \\
\text { experiment }\end{array}$ & $\begin{array}{c}\text { After } \\
\text { experiment }\end{array}$ \\
\hline Experimental & 37,0 & 70,4 & 63,0 & 29,6 \\
\hline Control & 33,3 & 40,7 & 66,7 & 59,3 \\
\hline
\end{tabular}

Among the above methods of overcoming barriers to the frequency of use in the experimental group, the following statements prevail: 
- $\quad$ I focus on the problem and think how it can be solved;

- I I remember how I solved similar problems before;

- $\quad$ I try to get into the situation;

- $\quad$ I reflect on what happened and my attitude to this event;

- $\quad$ I analyze the problem before reacting to it;

- $\quad$ I decide what is the most important for me to do;

- $\quad$ I control the situation;

- $\quad$ I develop several different options for solving the problem;

- $\quad$ I try to mobilize to emerge victorious from the situation;

- $\quad$ I try to distribute my time carefully;

- $\quad$ I determine the direction of actions and adhere to it.

The control group noted the following reactions and methods of overcoming barriers:

- $\quad$ I accuse myself of indecision;

- $\quad$ I feel irritated;

- $\quad$ I'm worried about what I'm going to do;

- $\quad$ I plunge into my pain and suffering;

- $\quad$ I am worried that I cannot cope with the situation;

- $\quad$ I feel nervous tension;

- $\quad$ I blame myself for being in this situation;

- $\quad$ I tell myself that this is not happening to me;

- $\quad$ I talk to someone whose advice I especially appreciate;

- $\quad$ I stop and I don't know what to do;

- $\quad$ I shout at relatives;

- $\quad$ I think about something good that happened in my life;

- $\quad$ I feel emotional shock;

- $\quad$ I hope that everything will be solved by itself;

- I panic.

Comparing the experimental and control groups, we note that in accordance with the majority of officers of the experimental group after the conducted program there is an independent continuation of work on the development of self-skills to actualize and support the positively colored emotional, volitional, intellectual states necessary for professional activity: patience, endurance, kindness, sympathy, restraint, satisfaction with what has been achieved. They consider it necessary and demonstrate certain behavioral manifestations: the ability to listen, the ability to analyze, the habit of bringing the case to its logical conclusion. 
In the situation of the barrier, the officers of the experimental group adequately perceive the difficult events, analyze them, control their own state, and take care of themselves. Officers of the control group in negative barrier situations feel negatively colored emotional, volitional, intellectual states: irritation, tension, emotional shock, inability to act, reluctance to take pity on and resolve the situation, withdrawal from difficulties and more descriptions. Thus, in barrier situations, the officers with whom systematic work on the development of barrier-resistant behavior was conducted are adequately perceived difficult events, analyze them, control their own state, take responsibility for resolving the situation, that is, they have higher barriers and more opportunities to increase their professional activity; therefore, the effectiveness of the professional activities of border guards depends on the systematic conduct of the proposed set of activities.

The analysis of the essence of psychological barriers in the activity of the border guard showed during the COVID-19 pandemic that when he experiences difficulties, the following problems occur. which make it impossible to establish certain means of service and combat activities and communication (uncertainty, anxiety, tension, fear, dissatisfaction, stress), which will lead to a premature decrease in efficiency and effectiveness. At the same time, the problem of the officer's barrier-resistanse remains unresolved, there are specific systematic researches of features of barrier resistance in professional activity, their specifics at different stages of professional formation and development of the personality of the officer of the State Border Guard Service of Ukraine, there are no programs to deal with the formation of various options for regulating barriers.

\section{Conclusions}

General loss of strength, lack of positive emotions, aggressive, unsatisfied reaction on the environment, increased irritability during the COVID-19 pandemic accompany the psychological state of the border guard. These manifestations and, moreover, their complex strongly complicate relations of the officer with subordinates, the top management, colleagues on service, in their own family, and, as a rule, affect their professional activity, reducing their efficiency, success, and, as a result, make it even more difficult.

Tense situations, which often arise in professional activities, are perceived as compulsive barriers, which threaten not only the activities but also the officer's life. So, the necessity of carrying out systematic, complex 
preventive work, including the measures of general and special importance, becomes extremely important.

The main content of the general direction of preventive work should be the weakening and elimination of social and socio-psychological preconditions which contribute to the formation of psychological barriers.

The components of such work are:

1. Integrated organization of professional activity and recreation of the officer.

2. Prevention and elimination of excessive emotional stress in the staff (conflicts between members, heightened emotional tensions).

3. Detection of people with low barrier resistance, organization of corrective measures for the development of skills of physical self-regulation, adequate removal of psychic tension.

4. Timely rendering of effective assistance by a military psychologist to an officer who is in a state of psychological crisis.

5. The conducted research does not conclude all aspects of the problem of resistanse of border guards to overcoming psychological barriers in the context of the COVID-19 pandemic. In our opinion, the study of the peculiarities of the manifestation of officers' psychological barriers with different cognitive styles requires more attention, training of officers to carry out collective-distribution activities with elements of psycho-training. It is of interest and research of the gender aspect of the mentioned problem.

\section{References}

Oleshko, D. (2014). Development of the ability to overcome psychological barriers in border guards [Doctoral dissertation]. National Academy of the State Border Guard Service of Ukraine named after Bohdan Khmelnytsky.

Orlov, Y. (2006). Healing (sanogenic) thinking. In A. V. Rebionok Series: Behavior Management (1 ${ }^{\text {st }}$ vol.). Moskow.

Pomytkin, E. (2020). Challenges of the present and priorities of modern education. individuality in the psychological dimensions of communities and professions. In Collection of scientific papers (pp. 212-216). LLC "Alfa-PIK".

Rybalka, V., Pomitkin, E., Ignatovych, O., Pavlyk, N., Ivanova, O., Radzimovska, O., Stanovskykh, Z., Kalyuzhna, E., \& Kabish-Ribalka, T. (2020). Psychological prevention and personal hygiene in counteracting the pandemic COVID-19. Kyiv Ivan Zyazyun Institute of Pedagogical and Adult Education of the National Academy of Pedagogical Sciences of Ukraine. 
Ability to Overcome Border Guards' Psychological Barriers During the ... Dmytro OLESHKO, et al.

Steenkamp, M., Litz, B., Hoge, C., \& Marmar, C. (2015). Psychotherapy for military-related PTSD: a review of randomized clinical trials. JAMA, 314(5), 489-500. https://doi.org/10.1001/jama.2015.8370

World Heath Organization (WHO). (2020). WHO Director-General's opening remarks at the media briefing on COVID-19 - 11 March 2020. https://www.who.int/dg/speeches/detail/who-director-general-sopening-remarks-at-the-media-briefing-on-covid-19-11-march-2020

Zgueb, Y., Bourgou, S., Neffeti, A., Amamou, B., Masmoudi, J., Chebbi, H., Somrani, N., \& Bouaskeri, A. (2020). Psychological crisis intervention response to the COVID 19 pandemic: A Tunisian centralised Protocol. Psychiatry Research, 289, p. 113042. https://doi.org/10.1016/i.psychres.2020.113042 